DOI: https://doi.org/10.18371/fp.4(44).2021.627176

УДК 658.5:012

\title{
СТРАТЕГІЧНІ ЗАВДАННЯ ТА УМОВИ ПІДВИЩЕННЯ РІВНЯ ЕКОЛОГІЧНОЇ ВІДПОВІДАЛЬНОСТІ МЕТАЛУРГІЙНИХ ПІДПРИєМСТВ
}

\author{
КАСИЧ Алла Олександрівна \\ доктор економічних наук, професор, \\ завідувач кафедри управління та смарт-інновацій \\ Киїського національного університету технологій та дизайну \\ ORCID ID: https://orcid.org/0000-0001-7019-1541
}

\section{СЕМЕНЮК Вікторія Сергї̈вна}

студентка кафедри управління та смарт-інновацій

Київського начіонального університету технологій та дизайну

ORCID ID: https://orcid.org/0000-0002-1443-1384

Анотація. У статті розкрито поняття «екологічна відповідальність» та критерії, щзо його характеризують. Проаналізовано сучасний рівень екологічної відповідальності в Украӥні. Визначено, щзо перед украӥнськими металургійними підприємствами стоїть необхідність підвищення екологічної сочіальної відповідальності з метою запобігання негативному впливу на навколишнє середовище.

Ключові слова: екологічна відповідальність, екологічна політика, корпоративна екологічна відповідальність.

Постановка проблеми. Паризька угода 2015 року, яка передбачає здійснення комплексних заходів зі зменшення шкідливих викидів всіма державами, є викликом і для українських підприємств, в тому числі металургійної галузі.

Сталь має велике значення і для сучасних економік, а тому в найближчі десятиліття глобальний попит на
Аннотация. $B$ cmaтье раскрыто понятие «экологическая ответственность» и характеризуюшие его критерии. Проанализирован современный уровень экологической ответственности в Украине. Определено, что перед украинскими металургийными предприятиями стоит необходимость повышение экологической сочииальной ответственности с иелью предотвращения негативного воздействия на окружающую среду.

Ключевые слова: экологическая ответственность, экологическая политика, корпоративная экологическая ответственHость.

сталь, як очікується, зростатиме. Задоволення цього попиту створює проблеми для металургійного сектору, оскільки він прагне прокласти більш екологічно-відповідальний шлях, залишаючись конкурентоспроможним. На даний момент металургія формує близько 8\% світового кінцевого попиту на енергію і здійснює 7\% викидів $\mathrm{CO} 2$ (включаючи викиди технологіч- 
них процесів) [1]. Однак завдяки інноваціям, розгортанню низьковуглецевих технологій та ефективності використання ресурсів виробники чавуну та сталі мають велику можливість зменшити споживання енергії та викиди парникових газів, розробити більш стійкі продукти та підвищити свою відповідальність за діяльність саме в екологічній площині.

Європейська металургія має продемонструвати 55-відсоткове зниження викидів СО2 вже у 2030 році, а у 2050 році - достягнути кліматичної нейтральності [2].

Українська металургія забезпечує левову частку експорту України, на чому наголошено в статті [23], а отже завдання підвищення рівня екологічної відповідальності - це питання підвищення конкурентоспроможності українських підприємств, що мають, відповідно, стратегічне значення.

За таких умов відповідні завдання щодо зниження викидів за рахунок підвищення екологічної відповідальності стоять і перед українськими металургійними підприємствами. Вирішення цих завдань потребує комплексного осмислення поняття «екологічна відповідальність», формування системного механізму управління питаннями взаємодії 3 навколишнім середовищем та розробки дієвих заходів щодо активізації цих процесів на корпоративному рівні на основі імплементації позитивного досвіду.

Аналіз останніх досліджень і публікацій. Питання корпоративного управління розглядаються як зарубіжними, так і вітчизняними вченими. Слід вказати праці Ж. Дерій [4], Г. Купалова [5], Т. Довгої [6], Е. Камишникова [7], М. Черноусової [8], С. Бендас [9], Н. Волосковець [11],
О. Охріменко [10], В. Огородник [11], О. Грішнова [12] та інших.

Розглянемо різні погляди авторів стосовно позицій впровадження екологічного аспекту корпоративної соціальної відповідальності у діяльності підприємств. Погляди авторів на рахунок цих позицій можна згрупувати за декількома основими напрямами. А. Зінченко [14], С. Бендас [9], Л. Бобко [13], Н. Волосковець [11], О. Охріменко [10], В. Огородник [11], О. Грішнова [12] вбачають серед основних критеріїв екологічної корпоративної відповідальності дотримання екологічних зобов'язань та стандартів.

Інша група авторів, таких як, Е. Камишникова [7], М. Черноусова [8] основний зміст екологічного аспекту корпоративної відповідальності розглядають через необхідність розроблення комплексу заходів для підвищення рівня ефективності екологічно відповідальних практик у галузі КСВ підприємств. В роботі [26] питання екологічної відповідальності розглядаються в системі управління стійким розвитком.

Ж. Дерій [4], Г. Купалова [5], Т. Довга [6] виокремлюють такий напрям як посилення роботи зі звітування та складання нефінансової звітності. Звітність зі стійкого розвитку $є$ важливою, оскільки дозволяє [3]: інформувати місцеві громади та органи влади про екологічні наслідки своєї діяльності; враховувати думки та побажання стейкхолдерів при розробці та реалізації власних проектів; забезпечувати прозорість екологічної діяльності.

Така увага до проблематики забезпечення екологічної відповідальності бізнесу підтверджує актуальність та потребує подальших досліджень. 
Метою статті $є$ дослідження стратегічних завдань та умов імплементації концепції екологічної відповідальності бізнесу на прикладі металургійних підприємств.

Виклад основних результатів дослідження. Ключовим питанням корпоративної відповідальності у сучасних умовах $\epsilon$ екологічна відповідальність, підвищення рівня якої є стратегічним завданням не лише для власне підприємств, а й для регіональної влади та держави в цілому.

Екологічна відповідальність порізному трактується представниками бізнесу та влади. Для бізнесу - питання екологічної відповідальності традиційно не $\epsilon$ в пріоритеті, оскільки вимагає суттєвих витрат, а отже призводить до зменшення доступної величини прибутку. По іншому ці питання розглядаються з боку суспільства. Підвищення суспільної уваги до екологічної складової відповідальності зумовлене загостренням екологічних проблем, які мають негативний вплив на умови життєдіяльності людей та $\epsilon$ джерелом техногенних катастроф та змін клімату, що негативно впливатиме на людство і у майбутньому.

Для розуміння предметної сфери здійснення управлінської діяльності щодо екологічної відповідальності необхідно для початку узагальнити зміст поняття «екологічна відповідальність» (табл. 1).

Таблиця 1

Поняття екологічної відповідальності

\begin{tabular}{|c|c|c|}
\hline Автор & Зміст & $\begin{array}{c}\text { Ключова характеристика } \\
\text { (акцент) }\end{array}$ \\
\hline $\begin{array}{l}\text { Директива } \\
\text { 2004/35/СС } \\
{[22]}\end{array}$ & $\begin{array}{l}\text { Екологічна відповідальність }(\mathrm{EB})-\text { зо- } \\
\text { бов’язання забруднювача вжити заходи із за- } \\
\text { побігання настанню екологічної шкоди чи } \\
\text { ліквідації наслідків екологічної шкоди для } \\
\text { відновлення природних ресурсів до стану, що } \\
\text { існував до її заподіяння, та покриття ним вит- } \\
\text { рат на проведені заходи. }\end{array}$ & $\begin{array}{l}\text { Зобов’язання бізнесу щодо } \\
\text { ліквідації наслідків еко- } \\
\text { логічної шкоди. }\end{array}$ \\
\hline $\begin{array}{l}\text { Смоленніков } \\
\text { Д. О.[24] }\end{array}$ & $\begin{array}{l}\text { ЕВ - законна і добровільна діяльність, здатна } \\
\text { підвищити конкурентоспроможність фірми та } \\
\text { закріпити ії репутацію під впливом різних } \\
\text { соціально-економічних агентів. }\end{array}$ & Вплив зацікавлених осіб. \\
\hline $\begin{array}{l}\text { Holtbrugge D., } \\
\text { Dogl C. [25] }\end{array}$ & $\begin{array}{l}\text { ЕВ - зобов’язання осіб, що приймають рішен- } \\
\text { ня, запроваджувати дії, спрямовані на захист і } \\
\text { поліпшення стану навколишнього середовища } \\
\text { в цілому, і які також відповідають їх власним } \\
\text { інтересам. }\end{array}$ & $\begin{array}{l}\text { Діяльність із захисту нав- } \\
\text { колишнього середовища. }\end{array}$ \\
\hline $\begin{array}{l}\text { Огородник } \\
\text { В.В. [17] }\end{array}$ & $\begin{array}{l}\text { ЕВ - діяльність як кожного окремого громадя- } \\
\text { нина, так і бізнес-структур, яка приносить ко- } \\
\text { ристь навколишньому природному середовищу } \\
\text { (або зменшує негативний вплив на навколишнє } \\
\text { середовище). }\end{array}$ & $\begin{array}{l}\text { Багаторівневий підхід фор- } \\
\text { мування відповідальності. }\end{array}$ \\
\hline $\begin{array}{l}\text { Мазуркевич } \\
\text { П. [15] }\end{array}$ & $\begin{array}{l}\text { ЕВ - добровільне намагання корпорацій } \\
\text { виміряти та мінімізувати екологічні наслідки } \\
\text { своєї підприємницької діяльності. }\end{array}$ & $\begin{array}{l}\text { Добровільний, } \\
\text { ний характер } \\
\text { діяілійсненле- } \\
\text { зіянсті } 3 \text { відповідаль- } \\
\text { ності. }\end{array}$ \\
\hline
\end{tabular}

Джерело: складено автором на основі $[15,16,17,18,19]$ 
Таким чином, поняття екологічної відповідальності за змістовними характеристиками визначає предметне поле управлінської діяльності, яке має стосуватись: мінімізації негативних впливів; пошуку можливостей конвергенції екологічних питань 3 економічними цілями та необхідних умов їх досягнення; формування системного базису реалізації принципів екологічної відповідальності.

Важливість здійснення системного управління питаннями екологічної відповідальності є важливим 3 позицій розуміння основних функцій, які реалізуються в ході здійснення заходів 3 підвищення рівня екологічної відповідальності. Так в ході управління екологічною відповідальністю реалізуються такі основні функції [3]:

компенсаиійна - спрямована на кількісну оцінку еколого-економічного збитку від діяльності та відповідного відновлення (компенсування) майнових та інших втрат;

превентивна - реалізується у формі примусових засобів впливу на поведінку учасників екологічних відносин за допомогою застосування покарання та відшкодування завданих збитків;

стимулююча - формування та використання економічних та нормативноправових стимулів до охорони довкілля;

бюджетна - здійснення екологічно значимих інвестицій бізнесом, що «розвантажує» бюджети всіх рівнів;

культурно-просвітницька - пов'язана із освоєнням нової парадигми управління, яка передбачає активну участь бізнесу у формуванні високого рівня корпоративної культури, вплив на споживацьку поведінку з урахуванням екологічних, енергетичних та кліматичних чинників.
Реалізація зазначених функцій вимагає від компаній створення цілісної системи управління екологічною відповідальністю. Однак для розуміння ключових складових системи управління, обгрунтування стратегічних завдань у сфері екологічної відповідальності необхідно сформувати чітке розуміння критеріїв, за якими підприємство може бути віднесено до екологічно-відповідального.

В науковій літературі [12, 23] зазнаються такі основні критерії визначення екологічно відповідальної компанії: відповідність екологічним нормам; зобов'язання, управління енергією та сировиною; ефективне залучення зацікавлених сторін. Зазначені критерії фактично визначають зміст заходів екологічно-відповідальної компанії. Так, у контексті дотримання екологічних норм підприємства при здійсненні виробництва не повинні перевищувати допустимі показники впливу на навколишнє середовище. Екологічні норми, прийняті в державі, мають на меті не лише виконання взятих міжнародних зобов'язань, а й покращення стану навколишнього середовища в країні. У випадку, якщо підприємство не дотримується екологічного законодавства воно має відшкодувати завдану шкоду. За таких умов механізм забезпечення відповідності екологічним нормам $\epsilon$ потужним драйвером здійснення екологічних інвестицій на основі системного управління. Важливим критерієм екологічно-відповідального підприємства $\epsilon$ раціональне використання ресурсів та екологічно-безпечне поводження 3 відходами, основою чого має стати впровадження ресурсо-ефективних технологій. Третій критерій в рамках взаємодії зі стейкхолдерами передба- 
чає не лише формування внутрішньої корпоративної культури, а й поширення іiї серед населення регіону.

Відповідність підприємства цим критеріям може бути досягнута лише за рахунок розробки стратегії підвищення екологічної відповідальності, реалізація якої вимагає значних фінансових витрат.

Для визначення стратегічних завдань та умов підвищення рівня еко- логічної відповідальності українських підприємств розглянемо тенденції, які мають місце в промисловості та використаємо досвід металургійних підприємств.

Динаміка промислового виробництва в останні роки не є стійкою, однак навіть в роки скорочення обсягів виробництва відбувалось збільшення обсягів утворених відходів (табл. 2).

Таблиця 2

Показники техногенного навантаження промисловості у порівнянні $з$ динамікою металургійного виробництва в Україні

\begin{tabular}{|l|c|c|c|c|c|c|}
\hline \multicolumn{1}{|c|}{ Показники } & 2015 & 2016 & 2017 & 2018 & 2019 & 2020 \\
\hline $\begin{array}{l}\text { Індекси промислової } \\
\text { продукції }\end{array}$ & 87,7 & 104,0 & 101,1 & 103,0 & 99,5 & 95,5 \\
\hline $\begin{array}{l}\text { Обсяг утворених від- } \\
\text { ходів, тис.т. }\end{array}$ & 312267,6 & 295870,1 & 366054 & 352333,9 & 441516,5 & 462373,5 \\
\hline $\begin{array}{l}\text { Індекси утворених від- } \\
\text { ходів }\end{array}$ & 87,96 & 94,75 & 123,72 & 96,25 & 125,31 & 104,72 \\
\hline $\begin{array}{l}\text { Загальний обсяг від- } \\
\text { ходів, накопичених } \\
\text { протягом експлуатації, } \\
\text { у спеціально відведе- } \\
\text { них місцях та об'єктах, } \\
\text { тис. т. }\end{array}$ & 12505915 & 12393923 & 12442168 & 12972428 & 15398649 & 15635259 \\
\hline $\begin{array}{l}\text { Обсяги викидів забруд- } \\
\text { нюючих речовин, тис. } \\
\text { т. }\end{array}$ & 4521,3 & 4686,6 & 4230,6 & 4121,2 & 4108,3 & - \\
\hline $\begin{array}{l}\text { Капітальні інвестиції на } \\
\text { охорону навколишньо- } \\
\text { го природного середо- } \\
\text { вища, тис. грн. }\end{array}$ & 7675597 & 13390477 & 11025535 & 10074279 & 16255671 & 13239649 \\
\hline $\begin{array}{l}\text { Індекси капітальних } \\
\text { внвестицій }\end{array}$ & 96,43 & 174,46 & 82,34 & 91,37 & 161,36 & 81,45 \\
\hline $\begin{array}{l}\text { Обсяг виробництва ме- } \\
\text { талургійного вироб- } \\
\text { ництва, млн. грн. }\end{array}$ & 278502,8 & 318195,9 & 411372,3 & 492706,7 & 423533,6 & 395589,6 \\
\hline $\begin{array}{l}\text { Індекс металургійного } \\
\text { виробництва }\end{array}$ & 86,4 & 105,0 & 97,4 & 100,8 & 98,6 & 90,9 \\
\hline
\end{tabular}

Джерело: складено авторами за даними [20]

Металургійна галузь України забезпечує 13-15\% промислового виробництва, є однією з найбільш значимих в структурі експорту та забезпечила, наприклад в 2020p., доходи на рівні
7,69 млрд. дол. США. Разом з тим, забезпечення екологічної відповідальності корпорацій металургії $є$ важливим з багатьох причин: 
по-перше, підприємства галузі є основними забруднювачами в регіонах, де вони розміщені;

по-друге, спостерігається нестійка динаміка виробництва металургії на фоні збільшення викидів в Україні;

по-третє, нестійкі екологічні інвестиції не дозволяють здійснити масштабну технологічну модернізацію.

Далі розглянемо особливості управління екологічною відповідальністю на прикладі одного з українських металургійних підприємств ПАТ «АрселорМіттал Кривий Ріг».

«АрселорМіттал» $є$ найбільшим іноземним інвестором та лідером металургійної промисловості України. Щорічно «АрселорМіттал Кривий Ріг» виробляє близько 6 мільйонів тон сталі, понад 80\% своєї продукції експортує. Компанія є яскравим прикладом, укра- їнської компанії, яка імплементує принципи екологічної відповідальності: реалізує програми 3 технологічної модернізації, нарощує інвестиції в охорону навколишнього середовища. 3 іншого боку, саме компанія «АрселорМіттал Кривий Ріг» $є$ основним забруднювачем в Дніпропетровській області. Величина валових викидів підприємства в 2019 р. становила 230,8 тис. т. у порівнянні з 208,2 тис. т. у 2018 р. [27]. Збільшення викидів забруднюючих речовин в атмосферне повітря на 10,9 \% пов'язано зі збільшенням обсягів виробництва, що свідчить про недостатню результативність у питаннях підвищення екологічної відповідальності. Основні показники, які характеризують екологічну відповідальність «АрселорМіттал Кривий Ріг», відображені в табл. 3. Таблиця 3

Основні показники, що характеризують екологічну відповідальність та умови її підвищення

\begin{tabular}{|l|c|c|c|c|c|}
\hline \multicolumn{1}{|c|}{ Показники } & 2016 & 2017 & 2018 & 2019 & 2020 \\
\hline $\begin{array}{l}\text { Виробництво прокату, } \\
\text { тис. тон. }\end{array}$ & 5624 & 5134 & 4197 & 4626 & 4468 \\
\hline $\begin{array}{l}\text { Доходи, млн. грн. } \\
\text { Чисельність персоналу, } \\
\text { осіб }\end{array}$ & 52961,8 & 66185,9 & 67963,2 & 62409226 & 63496684 \\
\hline Інвестиції, млн. дол. & 237,6 & 23815 & 20674 & 19973 & 19469 \\
\hline $\begin{array}{l}\text { Інвестиції в охорону } \\
\text { навколишнього середо- } \\
\text { вища, млн. грн. }\end{array}$ & 472 & 887 & 600 & 562,3 & 1584,9 \\
\hline $\begin{array}{l}\text { Загальне використання } \\
\text { енергії, млн. ГДж }\end{array}$ & 171,5 & 167,9 & 146,9 & вд & вд \\
\hline $\begin{array}{l}\text { Питомий показник } \\
\text { енергосмності, } \\
\text { ГДж/тонна сталі }\end{array}$ & 27,3 & 29,0 & 30,9 & вд & вд \\
\hline $\begin{array}{l}\text { Споживання енергії, } \\
\text { ГДж }\end{array}$ & 171481963 & 167861715 & 146875389 & вд & вд \\
\hline Викиди пилу, ти. тон & 33,1 & 32,1 & 20,4 & вд & вд \\
\hline $\begin{array}{l}\text { Питомий показник ви- } \\
\text { кидів, кг на тону сталі }\end{array}$ & 5,5 & 5,5 & 4,3 & вд & вд \\
\hline
\end{tabular}

Джерело: побудовано авторами на основі [21]

Виробництво сталі пов'язане зі споживанням значної кількості палива та зі значним промисловим впливом на навколишнє середовище. 
Представлені дані свідчить про те, що загальне споживання енергії скорочується, однак це не є позитивною ознакою, оскільки це відбувається на фоні зростання показника питомої енергоємності.

3 2006-го по 2019 рік «АрселорМіттал Кривий Ріг» інвестував в екологію 6,8 млрд грн, реконструйовано та побудовано понад 120 високоефективних газоочисних установок. 32006 до 2021 року загальні викиди в атмосферу вдалось знизити на $48,1 \%$, скид стічних вод - на $81,3 \%$, розміщення відходів - на $30,7 \%$.

Основними завданнями «АрселорМіттал Кривий Ріг» у галузі екології на майбутнє $є$ виконання екологічних зобов'язань та досягнення екологічної безпеки.

Серед ключових завдань, які ставить пере собою підприємство слід зазначити: зниження викидів парникових газів; проведення технологічної модернізації; збільшення частки інвестицій в екологію в загальній величині інвестицій.

«АрселорМіттал Кривий Ріг» для ефективного вирішення екологічних проблем є одним із перших металургійних підприємств в Україні, яке сформувано систему екологічного менеджменту. Компанія щорічно підтверджує відповідність вимогам міжнародного стандарту ISO 14001:2015, що засвідчує надійність та високу ефективність системи екологічного менеджменту. На підприємстві прийнята Екологічна політика, яка визначає основні принципи ставлення підприємства до охорони навколишнього середовища(табл. 4).

Таким чином, рівень екологічної відповідальності - це управлінське рішення самого підприємства, яке завжди формується на основі протиріч між економічними, соціальними та екологічними інтересами.

Таблиця 4

Основні принципи та зобов'язання «АрселорМіттал Кривий Ріг» щодо екологічної політики

\begin{tabular}{|l|l|}
\hline Цінності & \multicolumn{1}{|c|}{ Життя та здоров'я людини у екологічно чистому середовищі } \\
\hline Принципи & $\begin{array}{l}\text { Відповідність, системність та відкритість; } \\
\text { Попередження впливу і готовність; } \\
\text { Обізнаність і відповідальність. }\end{array}$ \\
\hline & $\begin{array}{l}\text { Виконувати природоохоронні заходи для постійного поліпшення екологічних показ- } \\
\text { ників та поетапного досягнення екологічних стандартів. } \\
\text { Впроваджувати енерго- та ресурсозберігаючі технології з метою раціонального ви- } \\
\text { користання природних ресурсів. } \\
\text { Ефективно та відповідально використовувати природні ресурси з високим ступенем } \\
\text { переробки відходів. } \\
\text { Поетапно розбудовувати екологічний моніторинг атмосферного повітря з інфор- } \\
\text { маційним забезпеченням. } \\
\text { Підтримувати відкритість екологічної інформації та співробітництво з усіма зацікав- } \\
\text { леними сторонами для прийняття рішень в сфері охорони навколишнього середови- } \\
\text { ща. } \\
\text { Забезпечувати екологічну освіту та загальне залучення в екологічну діяльність } \\
\text { співробітників підприємства. } \\
\text { Постійно удосконалювати систему екологічного менеджменту для зниження значи- } \\
\text { мості екологічних аспектів. } \\
\text { Популяризувати природоохоронну діяльність підприємства та впроваджувати } \\
\text { соціальні проєкти екологічної спрямованості. }\end{array}$ \\
Успішне поєднання бізнесу та екологічних інтересів суспільства.
\end{tabular}


I якщо раніше переважали економічні, а потім - соціальні цілі, то в даний час найбільшого значення має постановка та досягнення екологічних цілей. Загалом це є досить складний управлінський процес, оскільки забезпечення екологічної відповідальності потребує значних зусиль від підприємства, перш за все, фінансових, тоді коли результати знаходяться в площині соціальної значимості.

Висновки. В сучасних умовах відбувається підвищення рівня вимог до діяльності підприємств, які згідно концепції сталого розвитку стосуються не лише економічних результатів діяльності та цілей соціального розвитку, а, перш за все, результатів у сфері екології.
Забезпечення екологічної відповідальності підприємств повинно відбуватись 3 урахуванням вимог:

наднаціонального (міжнародного) рівня, який проявляється у формуванні міждержавних угод та стандартів щодо екологічної поведінки підприємств;

національного (державного рівня) більшість країн світу мають відповідні міністерства, формують екологічну політику.

Підвищення рівня екологічної відповідальності 3 позицій управління являє собою складний процес перетворення входів - ресурсів в комплекс вихідних елементів - продукції, саме цей підхід повинен бути взятий за основу на українських підприємствах.

\section{Список використаної літератури}

1. Iron and Steel Technology Roadmap Towards more sustainable steelmaking. reserved. International Energy Agency, 2020, 190 p. URL: https://iea.blob.core.windows.net/assets/eb0c8ec1-3665-4959-97d0187ceca189a8/Iron_and_Steel_Technology_Roadmap.pdf (дата звернення: $09.12 .2021)$

2. Зелена металургія: чому в Україні не працює ні один фінансовий стимул для декарбонізації промисловості. URL: https://www.epravda.com.ua/rus/projects/ekopromyslovist/2021/04/19/673017/ (дата звернення: 09.12.2021)

3. Defining Corporate Environmental Responsibility: Canadian ENGO Perspectives. URL: http://www.pollutionprobe.org/old_files/Reports/cerreport.pdf (дата звернення: 09.12.2021)

4. Дерій Ж. В., Зосименко Т. І. Екологічна компонента корпоративної соціальної відповідальності: світовий досвід та українські реалії. Актуальні проблеми економіки. 2016. No 11(185). С. 278-290.

5. Купалова Г., Матвієнко Т. Екологічна звітність підприємств як складова національної інформаційної системи з охорони довкілля. Вісник Київького національного університету ім. Т. Шевченка. Сер. Економіка. 2012. Вип. 142. С. 12-16.

6. Довга Т. Формування екологічної звітності сміттепереробних підприемств. Вісник Київського національного університету ім. Т. Шевченка. Сер. Економіка. 2012. Вип. 143. С. 50-53. 
7. Камишникова Е. В. Аналіз екологічних аспектів корпоративної соціальної відповідальності в об єднаннях підприсмств України. Економічний аналіз. 2017. T. 27. No 4. C. 205-210.

8. Черноусова М. А., Борема А. С. Экологический аспект развития корпоративной социальной ответственности в условиях глобализации мировой экономики. Проблемы развития внеинеэкономических связей и привлечетия иностранных инвестиций: ремональный аспект. 2014. N 2. С. 415-420.

9. Бендас С. В. Екологічна відповідальність як складова соціальної відповідальності. Актуальні проблеми теорії та практики менеджменту. 2017. C. 38-39. URL: https://economics.opu.ua/files/science/men/2017/38.pdf

10. Охріменко О. О., Іванова Т. В. Соціальна відповідальність. Київ: Національний технічний університет України «Київський політехнічний інститут», 2015. $180 \mathrm{c}$.

11. Огородник В.В. Вплив екологічного компонента соціальної відповідальності на економіку країни. Миколаӥвський національний університет імені В.О. Сухомлинського. 2015. Вип 7. С. 612-616.

12. Грішнова О. А., Думанська В. П. Екологічний вектор соціальної відповідальності. Економіка і управління. 2011. 3. С. 32-38.

13. Бобко Л. Сучасний стан та перспективи розвитку корпоративної соціальної відповідальності в Україні. Ефективність державного управління. 2016. Вип. 1/2 (46/47). Ч. 2. С. 41-47

14. Зінченко А., Саприкіна М. Розвиток КСВ в Україні: 2010-2018. Київ: Видавництво «Юстон», 2017. 52 с.

15. Мазуркевич П. Корпоративна екологічна відповідальність: чи можлива спільна система KCВ? URL: Siteresources.worldbank.org (дата звернення: 09.12.2021)

16. Freemen R. E. Strategic Management: A Stakeholder Approach. Boston: Pitman Publishing, 1984. $292 \mathrm{p}$

17. Огородник В.В. Вплив екологічного компонента соціальної відповідальності на економіку України. Глобальні та наџіональні проблеми економіки. 2018. Випуск 7. С.612-616.

18. Holtbrugge D., Dogl C. How International is Corporate Environmental Responsibility? A literature review. Journal of International Management. 2012. Vol 18. P. $180-195$

19. Шаповал В.М., Коваленко О.А. Функції та елементи соціальної відповідальності сучасних компаній. Детермінанти сталого розвитку організаиій в умовах глобалізаиіі : зб. тез доповідей I міжнар. наук.-практ. інтернет-конф., м. Дніпропетровськ, 15-16 груд. 2014 р., Нац. гірн.ун-т. Д.: НГУ, 2015. С.158-160.

20. Офіційний сайт Державної служби статистики України. URL: http://www.ukrstat.gov.ua/ (дата звернення: 09.12.2021)

21. Офіційний сайт ПАТ «АрселорМіттал Кривий Ріг» URL: https://ukraine.arcelormittal.com/index.php?id=265_(дата звернення: 09.12.2021) 
22. Екологічна відповідальність: досвід ЄC та можливості для України. URL: https://www.civic-synergy.org.ua/wp-content/uploads/2018/04/webenvironmentalliabilityua2018.pdf (дата звернення: 09.12.2021)

23. Касич А.О., Дідур С.В. Структурні характеристики зовнішньої торгівлі України. Актуальні проблеми економіки: науковий економічний журнал. (2008). № 1(79). С. 85-94.

24. Смоленніков Д. О. Роль екологічної відповідальності бізнесу на шляху до сталого розвитку. Вісник СумДУ. Серія Економіка. 2013. № 4, С.35-40.

25. Holtbrugge D., Dogl C. How international is corporate environmental responsibility? A literature review. Journal of international management. 2012. Vol 18. pp. 180-195.

26. Kasych A., Vochozka M. Medothological support of the enterprise sustainable development management. Маркетинг і менеджмент інноваиій. 2018. №1. С.371381

27. Звіт про стратегічну екологічну оцінку програми соціально-економічного та культурного розвитку Дніпропетровської області на 2021 рік. URL: https://adm.dp.gov.ua/storage/app/media/uploaded-files/seo-zvit-social-ekonomrozvitok-2020.pdf_(дата звернення: 09.12.2021) 